\title{
Diagnostic Value of Serum Autotaxin Levels in Liver Fibrosis in Children with Chronic Hepatitis
}

\author{
M.A.El-Baz ${ }^{1}$, O.G.Behairy ${ }^{1}$, A.I.Mansour ${ }^{2}$ and R.A.Elsayed ${ }^{3}$ \\ ${ }^{1}$ Pediatrics Dept., Faculty of Medicine, Benha Univ., Benha, Egypt \\ ${ }^{2}$ Clinical and Chemical Pathology Dept., Faculty of Medicine, Benha Univ., Benha, Egypt \\ ${ }^{3}$ (M.B.B.Ch), Faculty of Medicine, BenhaUniv., Benha. Egypt
}

\begin{abstract}
Liver biopsy is the most accurate examination method to evaluate liver fibrosis stage but is invasive. Non-invasive biomarkers of disease progression are therefore needed. The study aimed toassess the role of serum autotoxin levels in diagnosis of liver fibrosis in children with chronic hepatitis. This study was a case controlled study that was conducted on a total number of 80 children of both sex. 50 children (case group) collected from outpatient pediatric hepatology clinic of Benha University hospitals and National Liver Institute Monoufia University. 30 apparently healthy children (control group) matched the patient group in age and sex. All children subjected to full history taking, physical examination and Laboratory Investigations: CBC, AST, ALT, GGT, alkaline phosphatase, serum bilirubin, serum albumin, PT, PTT, INR, total protein, total serum IgG levels, hepatitis markers (HAV, HBV\&HCV), liver biopsy and serum autotaxin level by ELISA. There was statistical significant difference $(\mathrm{P}$ value $<0.01)$ among chronic hepatitis group and control group regarding $\mathrm{HB}$, platelet, total protein as they were lower in chronic hepatitis group than control group, while PT, INR, AST, ALT, GGT, ALP and bilirubin (total\& direct) were higher in chronic hepatitis group than control group.There was statistical significant differencebetween studied groups regarding serum autotaxin as it was elevated in chronic hepatitis group. There were statistical significant differences between serum level of autotaxin and fibrosis index, hepatitis activity index and interface hepatitis as it increases with increase fibrosis index, hepatitis activity index and interface hepatitis. The best cut off value of serum autotaxin was $10.45 \mathrm{ng} / \mathrm{ml}$ for detection of early fibrosis stage with sensitivity $97.6 \%$, specificity $93.8 \%$ and area under the curve is 0.961 while the best cut off serum autotaxin for detection of moderate fibrosis was $18.15 \mathrm{ng} / \mathrm{ml}$ with sensitivity $85 \%$, specificity $93.8 \%$ and area under the curve is 0.984 . Autotaxin may be a novel non-invasive biomarker for liver fibrosis done on Egyptian children with chronic hepatitis.
\end{abstract}

Keywords: Chronic hepatitis, Liver fibrosis, Autotaxin.

\section{Introduction}

Chronic liver disease refers to a wide spectrum of disorders characterized by ongoing liver damage with potential for progression to cirrhosis or end-stage liver disease(1).Chronic liver disease is most often caused by biliary atresia and genetic-metabolic diseases in infants while in older children, it tends to result from viral infection, autoimmune hepatitis, Wilson's disease, alpha 1-antitrypsin deficiency and primary sclerosing cholangitis (2).

Liver biopsy plays an important role in modern clinical practice in diagnosis of different types of chronic liver disease and assessment of disease severity including staging and grading. It is the most accurate examination method to evaluate liver fibrosis stage but is invasive, prone to sampling error and carries the risk of rare but serious complications. Non-invasive biomarkers of disease progression are therefore needed (3).

Autotaxin (ATX) also known as ectonucleotide pyrophosphatase/ phosphodi-esterase (ENPP) 2, is a secreted lyso-phospholipase D (lyso PLD) that belongs to the ENPP family. It plays an important role in converting lysophosphatidylcholine to the bioactive phospholipid lyso-phosphatidic acid (LPA) that stimulates the proliferation and contractility of hepatic stellate cells. Autotaxin was metabolized by liver sinusoidal endothelial cells so in liver fibrosis, there was retarded degradation of circulating ATX due to liver sinusoidal endothelial cell dysfunction from liver fibrosis (4).

\section{Subjects and methods}

This cross sectional case controlled study was conducted on a total number of 80 children of both sex. 50 children collected from attendance of outpatient pediatric hepatology clinic of Benha University hospitals and National Liver Institute Menoufia University after informed consent. 30 apparently healthy children were selected from general population during the period from January 2018 to May 2018. Laboratory work was conducted in clinical pathology department, Benha University hospitals.

This were devided into:

Group I (case group): included 50 children with chronic hepatitis included (28 females/ 22 males) their mean age \pm SD 7.58 \pm 5.47 years ranged from 6 months to 17 years.

Group II (control group): included 30 children apparently healthy matching the case group for age and sex included (17 females $/ 13$ males) their mean age \pm SD $7.12 \pm 5.40$ years ranged from 6 months to 17 years.

\section{Inclusion criteria}

All children less than 18 years old with chronic hepatitis of different etiology (e.g viral hepatitis, autoimmune hepatitis and cholestasis included extra hepatic biliary atresia, idiopathic neonatal hepatitis and giant cell hepatitis).

\section{Exclusion criteria}


Children with chronic liver diseases with comorbidities like renal diseases or heart diseases.

\section{Informed consent}

Informed consent was obtained from the parents after had been informed about all study procedures and their consent was obtained prior to children enrollment in the study.

\section{Ethical approval}

This study was approved by the ethical committee of the Faculty of Medicine, Benha University.

\section{Methods: All enrolled children were subjected to the} following:

A) Full history taking.

B) Clinical examination: Includinggeneral examination \&abdominal examination.

C) Abdominal ultrasound: For assessment of liver span, texture, spleen span and presence of ascites.

D) Laboratory investigations

1. Sampling

Venous blood was drawn by aseptic venipuncture using disposable syringe. Blood was divided in different tubes as follows: $1.5 \mathrm{ml}$ on EDTA for CBC, $2.5 \mathrm{ml}$ on Na-citrate for PT, and $3 \mathrm{ml}$ on plain tube that was allowed to clot at room temperature for $30 \mathrm{~min}$ then serum was separated by centrifugation for biochemical and serological testing

\section{Biochemica land hematological investigations:}

a) Complete blood count (CBC): was done by automated hematology analyzer (CELL-DYN Emerald, Germany) to determine hemoglobin level $(\mathrm{Hb})$, total leucocytic count (TLC) and platelets count (PLT).

b) Prothrombin time (PT), concentration, INR and activated partial thromboplastin time (aPTT) (STA Compact Max, STAGO, France).

c) Liver function tests: included serum total and indirect bilirubin, liver enzymes (ALT, AST, GGT, and alkaline phosphatase), serum total protein and albumin levels (BioSystems A25, Spain).

All biochemical tests were performed as a routine laboratory investigation by appropriate instruments and kits. The upper limits of normal (ULN) for ALT and AST were established as $40 \mathrm{IU} / \mathrm{L}$.

3. Viral markers, auto-antibodies and Immunoglobulin $\boldsymbol{G}(\mathrm{IgG})$

a) Hepatitis $\mathrm{B}$ surface antigen (HBsAg), anti-HBs antibodies, anti-HB core $\mathrm{Ab}$ (Igm and $\mathrm{IgG}$ ), anti-HCV $\mathrm{Ab}$ and anti-HAV $\mathrm{Ab}$ (IgM and $\mathrm{IgG}$ ) were tested by enzyme linked immunosorbent assay (ELISA) kit (Biokit, Spain).

b) Patients suspected to have autoimmune hepatitis were tested for serum autoantibodies including: antinuclear antibodies (ANA), anti-smooth muscle antibody (ASMA), liver kidney microsomal antibody1 (LKM1), and anti- mitochondrial antibody (AMA) by indirect immunofluorescence technique (NOVA Lite, Inova Diagnostics, Spain).

c) Immunoglobulin $\mathrm{G}(\mathrm{IgG})$ : By radial immunodiffusion using (IgG-NLRID, RN004.3, Binding site, Birmingham, UK).

\section{Ectonucleotide Pyrophosphatase/} Phosphodiesterase 2 (ENPP2) or Autotaxin level

A double-antibody sandwich ELISA (Enzyme Linked Immune Sorbent Assay) was used to detect serum level of Ectonucleotide Pyrophosphatase/ Phosphodiesterase 2 (ENPP2) or Autotaxin using a commercial Human (ENPP2) ELISA Kit for research use only (Cat \#: 201804, SunRedBio, China).

\section{Percutaneous liver biopsy}

Ultrasound guided liver biopsy done for all patients using Menghiniaspirarion needle (HepafixLuer Lock Melsungen AG, 3409 Mel-Sungen, Germany). Adequate core containing at least 5 portal tracts. Biopsy specimen were fixed in formaline and embedded in paraffin. Five $\mathrm{cm}$ thick section were cut, mounted on glass slide and stained with hematoxyline and eosin to evaluate histological activity of hepatitis using Ishak scoring index. Also stained with Mason-Trichrome to assess fibrosis stage. Table(I, II ) .

Table (I) Modified HAI Grading: Necro-inflammatory Scores

\begin{tabular}{|c|c|c|c|c|c|c|c|}
\hline $\begin{array}{l}\text { Periportal or } \\
\text { Periseptal } \\
\text { Interface } \\
\text { Hepatitis } \\
\text { (piecemeal } \\
\text { necrosis) } \\
\text { (A) }\end{array}$ & $\begin{array}{c}\text { Scor } \\
\text { e }\end{array}$ & $\begin{array}{l}\text { Confluent } \\
\text { Necrosis } \\
\text { (B) }\end{array}$ & $\begin{array}{c}\text { Sco } \\
\text { re }\end{array}$ & $\begin{array}{l}\text { Focal (spotty) Lytic } \\
\text { Necrosis, Apoptosis, } \\
\text { and Focal } \\
\text { Inflammation* } \\
\text { (C) }\end{array}$ & $\begin{array}{c}\text { sco } \\
\text { re }\end{array}$ & $\begin{array}{c}\text { Portal } \\
\text { Inflammat } \\
\text { ion } \\
\text { (D) }\end{array}$ & $\begin{array}{c}\text { Sco } \\
\text { re }\end{array}$ \\
\hline Absent & 0 & Absent & 0 & Absent & 0 & None & 0 \\
\hline $\begin{array}{l}\text { Mild (focal, few } \\
\text { portal areas) }\end{array}$ & 1 & $\begin{array}{c}\text { Focal confluent } \\
\text { necrosis }\end{array}$ & 1 & $\begin{array}{l}\text { One focus or less per } \\
10 \mathrm{x} \text { objective }\end{array}$ & 1 & $\begin{array}{c}\text { Mild, some } \\
\text { or all portal } \\
\text { areas }\end{array}$ & 1 \\
\hline $\begin{array}{c}\text { Mild/moderate } \\
\text { (focal, most portal } \\
\text { areas) }\end{array}$ & 2 & $\begin{array}{c}\text { Zone } 3 \text { necrosis } \\
\text { in some areas }\end{array}$ & 2 & $\begin{array}{l}\text { Two to four foci per } \\
\text { 10x objective }\end{array}$ & 2 & $\begin{array}{l}\text { Moderate, } \\
\text { some or all } \\
\text { portal areas }\end{array}$ & 2 \\
\hline Moderate & 3 & Zone 3 necrosis & 3 & Five to ten foci per & 3 & Moderate/ & 3 \\
\hline
\end{tabular}


- Total

Modified

/18.

activity

are defined

follows (1-

minimal;

$12 ; 13-18$,

- Does not

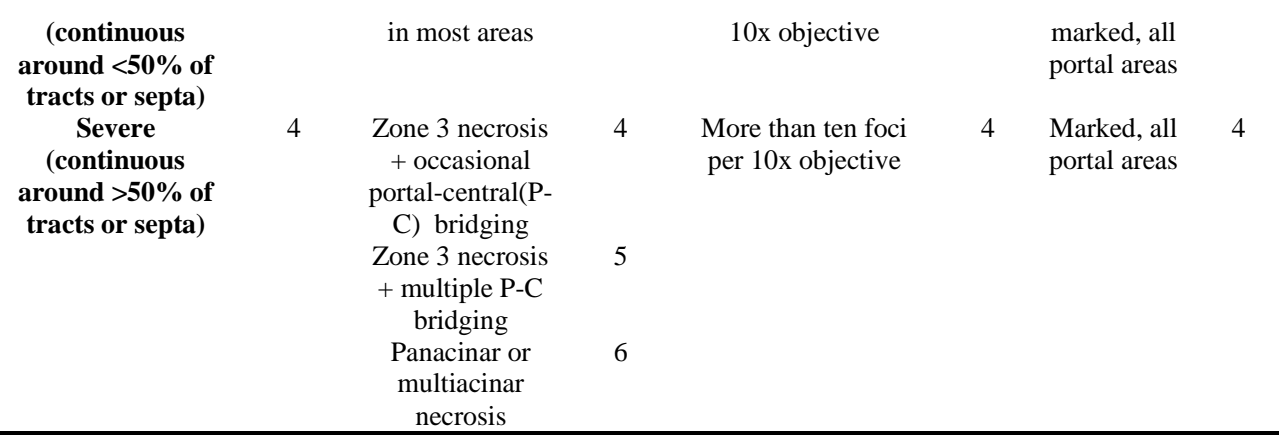

diffuse sinusoidal infiltration by inflammatory cells (5).
HAI $=$
Total
scores
as
$\quad 3$
mild 9-
sever).
include

Table (II) Modified Staging: Architectural changes, fibrosis and cirrhosis

\begin{tabular}{lc}
\hline Change & Score \\
\hline No fibrosis & 0 \\
Fibrous expansion of some portal areas, with or without short fibrous septa & 1 \\
Fibrous expansion of most portal areas, with or without short fibrous septa & 2 \\
Fibrous expansion of most portal areas with occasional portal to portal (P-P) bridging & 3 \\
Fibrous expansion of portal areas with marked bridging [portal to portal (P-P) as well & 4 \\
as portal to central (P-C)] & \\
Marked bridging (P-P and/or P-C) with occasional nodules (incomplete cirrhosis) & 5 \\
\hline Cirrhosis, probable or definite & 6 \\
\hline
\end{tabular}

Additional features which should be noted but not scored: Intra-acinar fibrosis, perivenular ('chicken wire' fibrosis) and phlebosclerosis of terminal hepatic venules (5).

The disease severity scoring systems

For predicting prognosis of end-stage liver disease, many prognostic models were proposed as:

a. PELD score (pediatric end stage liver disease score): It is a disease severity scoring system for children under 12 years of age. This score is used for prioritizing allocation of liver transplantsto predict survival. It is calculated according to the following formula :

PELD $=4.80 \times \operatorname{Ln}[$ serum bilirubin $(\mathrm{mg} / \mathrm{dl})]+$ $18.57 \times \operatorname{Ln}[\mathrm{INR}]-6.87 \times \operatorname{Ln}[$ albumin $(\mathrm{g} / \mathrm{dl})]+$ 4.36(if patient $<1$ year : score for patients listed for liver transplantation before the patient's first birthday continue to include the value assigned for age $(<1$ year) until the patient reaches the age of 24 months) +6.67 (if patient has growth failure $(<-2 \quad$ Standard deviation)). (In abbreviation for natural logarithm). Liver transplantation may be consider when the PELD score exceeds 4, and liver transplantation may be required immediately when the PELD score exceeds 22 (6)

b. MELD score (model for end-stage liver disease score): It is a scoring system for assessing the severity of chronic liver disease. It was found to be useful in determining prognosis and prioritizing for receipt of a liver transplant. It is calculated according to the following formula (6):

MELD $=3.78 \times \operatorname{Ln}[$ serum bilirubin $(\mathrm{mg} / \mathrm{dl})]+11.2 \times$ $\mathrm{Ln}[\mathrm{INR}]+9.57 \times \ln [$ serum creatinine $(\mathrm{mg} / \mathrm{dl})]+6.43$. (In abbreviation for natural logarithm). In interpreting the MELD Score in hospitalized patients, the 3 month mortality is:

- 40 or more $-71.3 \%$ mortality

- 30-39-52.6\% mortality

- 20-29-19.6\% mortality

- 10-19-6.0\% mortality

- $<9-1.9 \%$ mortality

\section{Child-Pugh score and classification_(Table III, IV )(7)}

(Table III)

\begin{tabular}{cccc}
\hline Measure & $\mathbf{1}$ point & $\mathbf{2}$ points & $\mathbf{3}$ points \\
\hline Total bilirubin, $\mu \mathrm{mol} / \mathrm{L}(\mathrm{mg} / \mathrm{dl})$ & $<34$ & $34-50(2-3)$ & $>50(>3)$ \\
& $(<2)$ & & $<2.8$ \\
\hline Serum albumin, g/dl & $>3.5$ & $2.8-3.5$ & $>6.0$ \\
\hline Prothrombin time, prolongation (s) & $<4.0$ & $4.0-6.0$ & Moderate to Severe (or refractory) \\
\hline Ascites & None & Mild (or suppressed with medication) & Grade III-IV \\
\hline Hepatic encephalopathy & None & Grade I-II & .
\end{tabular}

Chronic liver disease is classified into Child-Pugh class A to C, employing the added score from above.

Table IV:_Child-Pugh classification

\begin{tabular}{llll}
\hline Points & Class & One year survival & Two year survival \\
\hline
\end{tabular}




\begin{tabular}{cccc}
\hline $5-6$ & A & $100 \%$ & $85 \%$ \\
\hline $7-9$ & $\mathrm{~B}$ & $81 \%$ & $57 \%$ \\
\hline $10-15$ & $\mathrm{C}$ & $45 \%$ & $35 \%$ \\
\hline
\end{tabular}

\section{Statistical methods}

Results were organized, tabulated and statistically analyzed using SPSS software statistical computer package version 16. Qualitative data were expressed as number and percentage. For quantitative data, the mean and standard deviation and median were calculated. The difference between means was statistically analyzed using the student (t) test, Mann-Whitney test and ANOVA test when was suitable correlation analysis was done using Pearson(r) and Spearman (rho) correlation when was suitable. Receiver operator characteristic (ROC) curve was used to assess the performance of autotaxin in diagnosis of fibrosis.The accepted level of significance in this work was $0.05(\mathrm{p} \leq$ $0.05)$.

$P$ value $>0.05$ is non-significant (NS)

$P<0.05$ is significant $(S)$

$P \leq 0.001$ is highly significant $(H S)$

\section{Results}

Results in table(1) showed that there was statistical significant difference between chronic hepatitis patients and control group regarding weight, weight/ centile, height and height/ centile, body mass index (BMI) and $\mathrm{BMI} /$ centile as it was lower in chronic hepatitis group. Results in table (2) showed that there was statistical significant difference ( $\mathrm{P}$ value $<0.01$ ) between chronic hepatitis group and control group regarding $\mathrm{HB}$, platelet, total protein as they were lower in chronic hepatitis group than control group, while PT, INR, AST, ALT, GGT, ALP and bilirubin (total\& direct) were higher in chronic hepatitis group than control group. However, there was no statistical significant difference among chronic hepatitis group and control group regarding TLC, albumin and PTT. Results in table (3) showed that there was statistical significant difference between studied groups regarding serum autotaxin as it was elevated in chronic hepatitis group. Results in table (4) showed that there was statistical significant difference between serum autotaxin and sex as it was elevated in female patients. Results in table (5) showed that there were statistical significant differences between serum level of autotaxin and fibrosis index, hepatitis activity index and interface hepatitis as it increases with increase fibrosis index, hepatitis activity index and interface hepatitis. Results in table (6) showed that there was positive correlation between serum autotoxin and liver enzymes (PT, PTT, INR, AST, ALT, GGT, ALP and bilirubin (total\& direct)). However, there was negative correlation between serum autotaxin and hemoglobin, platelet and total protein. Results in table (7) showed that there was positive correlation between serum autotoxin and liver span, spleen size, APRI and FIB4. Results in table (8) showed that The best cut off value of serum autotaxin was $10.45 \mathrm{ng} / \mathrm{ml}$ for detection of early fibrosis stage with sensitivity $97.6 \%$, specificity $93.8 \%$ and area under the curve is 0.961 while the best cut off serum autotaxin for detection of moderate fibrosis was $18.15 \mathrm{ng} / \mathrm{ml}$ with sensitivity $85 \%$, specificity $93.8 \%$ and area under the curve

is

0.984 .

Table (1) Anthropometric measurements between studied groups

\begin{tabular}{lccccccc}
\hline \multirow{2}{*}{ Anthropometricmeasurements } & \multicolumn{2}{c}{ Chronic hepatitis group[n=50] } & \multicolumn{2}{c}{ Control group[n=30] } & \multirow{2}{*}{ T-Test } & \multicolumn{2}{c}{ P } \\
\cline { 2 - 6 } & value \\
\cline { 2 - 6 } & Mean \pm SD & Range & Mean \pm SD & Range & & \\
\hline Weight in kg & $25.26 \pm 12.93$ & $6-57$ & $31.5 \pm 9$ & $6-38$ & 2.32 & $<0.05$ \\
Weight / centile & $39.34 \pm 12.7$ & $3-75$ & $46.3 \pm 10.2$ & $3-90$ & 2.54 & $<0.05$ \\
Height in cm & $100.50 \pm 32.69$ & $65-140$ & $120 \pm 25$ & $61-160$ & 2.8 & $<0.05$ \\
Height / centile & $30.62 \pm 18.6$ & $3-75$ & $39.70 \pm 20.6$ & $5-90$ & U=660 & $<0.05$ \\
BMI & $17.03 \pm 2.27$ & $11-24$ & $22 \pm 8.3$ & $12-25$ & 4 & $<0.001$ \\
\hline BMI / centile & $39.22 \pm 26.15$ & $3-88$ & $59.80 \pm 22.77$ & $9-97$ & 3.57 & $<0.01$ \\
\hline
\end{tabular}

Table (2) Comparison between studied groups regarding some laboratory parameters

\begin{tabular}{|c|c|c|c|c|c|c|}
\hline \multirow[b]{2}{*}{ LAB } & \multicolumn{2}{|c|}{ Chronic hepatitis group $[n=50]$} & \multicolumn{2}{|c|}{ Control group $[\mathrm{n}=30]$} & \multirow{2}{*}{ T-test } & \multirow{2}{*}{$\mathbf{p}$} \\
\hline & Mean \pm SD & Range & Mean \pm SD & Range & & \\
\hline$\overline{H b}(g \backslash d L)$ & $10.55 \pm 1.07$ & $8-14$ & $11.60 \pm 1.3$ & $9-14$ & 3.6 & $<0.01$ \\
\hline $\operatorname{TLC}\left(\times 10^{3} \backslash \mu \mathrm{L}\right)$ & $8.41 \pm 1.48$ & $5.3-11.4$ & $825.36 \pm 273.82$ & $7-13$ & 0.292 & $>0.05$ \\
\hline Platelet $\left(\times 10^{3} \mid \mu \mathrm{L}\right)$ & $242.28 \pm 740.96$ & $70-452$ & $302.40 \pm 101.86$ & $170-568$ & 2.8 & $<0.01$ \\
\hline $\begin{array}{l}\text { total } \\
\text { protein }(g \backslash d L)\end{array}$ & $6.38 \pm 0.63$ & $5.6-6.5$ & $6.97 \pm 0.45$ & $6-7.9$ & & $\begin{array}{l}<0.00 \\
1\end{array}$ \\
\hline Albumin (g\dL) & $3.54 \pm 0.50$ & $2.6-5$ & $3.62 \pm 0.26$ & $3.1-4.3$ & 0.844 & $>0.05$ \\
\hline PT(Second) & $13.90 \pm 1.43$ & $12-18$ & $13.28 \pm 0.92$ & $12-14$ & 2.13 & $<0.05$ \\
\hline PTT(Second) & $33.99 \pm 3.94$ & $27-44$ & $32.87 \pm 2.06$ & $29-39$ & 1.6 & $>0.05$ \\
\hline
\end{tabular}




\begin{tabular}{|c|c|c|c|c|c|c|}
\hline \multirow{2}{*}{$\begin{array}{l}\text { INR } \\
\text { AST(IUVL) }\end{array}$} & $1.10 \pm 0.18$ & \multirow{2}{*}{$\begin{array}{l}1-1.7 \\
30-430\end{array}$} & $1.00 \pm 0.02$ & \multirow{2}{*}{$\begin{array}{l}1-1.1 \\
19-51\end{array}$} & 3.7 & $<0.01$ \\
\hline & $110.04 \pm 109.21$ & & $33.27 \pm 8.86$ & & $\mathrm{U}=167.5$ & $<0.00$ \\
\hline \multirow{2}{*}{$\begin{array}{l}\operatorname{AIT}(I U L) \\
\text { GGT(IUL) }\end{array}$} & $102.76 \pm 116.24$ & \multirow{2}{*}{$\begin{array}{l}24-458 \\
12-156\end{array}$} & $37.40 \pm 11.57$ & \multirow{2}{*}{$\begin{array}{l}16-59 \\
15-65\end{array}$} & $\mathrm{U}=476$ & $<0.01$ \\
\hline & $64.16 \pm 44.89$ & & $25.40 \pm 11.31$ & & $\mathrm{U}=286$ & $\begin{array}{l}<0.00 \\
1\end{array}$ \\
\hline ALP(IUL) & $290.74 \pm 222.14$ & $85-764$ & $86.77 \pm 30.96$ & $51-202$ & $\mathrm{U}=140.5$ & $\begin{array}{l}<0.00 \\
1\end{array}$ \\
\hline Bil.Total (mg\dL) & $2.33 \pm 1.79$ & $0.6-7.8$ & $0.90 \pm \mathbf{0 . 1 3}$ & $0.6-1.2$ & $\mathrm{U}=164$ & $\begin{array}{l}<0.00 \\
1\end{array}$ \\
\hline $\begin{array}{l}\text { Bil.Direct } \\
\text { (mgldL) }\end{array}$ & $0.70 \pm 1.15$ & $0.01-4.5$ & $0.09 \pm 0.0 ` 4$ & $0.02-0.16$ & $\mathrm{U}=380.5$ & $<0.01$ \\
\hline
\end{tabular}

Table (3) Comparison between studied groups regarding serum autotaxin level

\begin{tabular}{lccccc}
\hline & & Chronic hepatitis group(n=50) & Control group(n=30) & T Test & P \\
\hline Autotaxin(nglml) & Mean \pm SD & $19.65 \pm 5.56$ & $4.37 \pm 1.46$ & 18.4 & $<0.00$ \\
& Range & $10.2-28.3$ & $2.10-6.3$ & 1 \\
\hline
\end{tabular}

Table (4) Comparison between serum autotoxin and sex, consanguinity, family history of liver disease

\begin{tabular}{llllll}
\hline \multirow{2}{*}{ Variables } & & \multicolumn{2}{c}{ Autotaxin $(\mathbf{n g} \backslash \mathbf{m l})$} & \multirow{2}{*}{ Test } & \multirow{2}{*}{$\mathbf{p}$} \\
\cline { 3 - 4 } & & Mean \pm SD & Range & & \\
\hline Sex & Male & $10.75 \pm 6.9$ & $2.1-26.3$ & \multirow{2}{*}{$\mathrm{T}=3.12$} & $<0.01$ \\
\multirow{2}{*}{ Consanguinity } & Female & $16.38 \pm 9.14$ & $4.3-28.3$ & & \\
& Yes & $12.04 \pm 8.43$ & $3.2-27.5$ & \multirow{2}{*}{1.04} & $>0.05$ \\
Family history of liver disease & No & $14.46 \pm 8.73$ & $2.1-28.3$ & & \\
& Yes & $9.84 \pm 8.32$ & $2.5-25.1$ & \multirow{2}{*}{$\mathrm{U}=265.5$} & $>0.05$ \\
\hline
\end{tabular}

Table (5) Comparison between serum autotaxin and liver biopsy

\begin{tabular}{|c|c|c|c|c|c|}
\hline \multirow{2}{*}{\multicolumn{2}{|c|}{ Liver biopsy }} & \multicolumn{2}{|c|}{ Autotaxin (nglml) } & \multirow[t]{3}{*}{ F Test } & \multirow[t]{2}{*}{$\mathrm{p}$} \\
\hline & & \multirow{2}{*}{$\frac{\text { Mean } \pm \text { SD }}{17 \pm 3.9}$} & \multirow{2}{*}{$\frac{\text { Range }}{2.1-23.8}$} & & \\
\hline \multirow{3}{*}{ Fibrosis index (FI) } & No fibrosis $(0 / 6)$ & & & & \\
\hline & Mild fibrosis (1-2/6) & $20.7 \pm 5.4$ & $10.2-28.1$ & 3.48 & $<0.0$ \\
\hline & $\begin{array}{l}\text { Moderate fibrosis (3- } \\
4 / 6)\end{array}$ & $26.4 \pm 4.4$ & $18.1-30.3$ & & 5 \\
\hline \multirow{3}{*}{$\begin{array}{l}\text { Hepatitis activity } \\
\text { index (HAI) }\end{array}$} & Minimal & $17.52 \pm 5.6$ & $10.2-27.4$ & & \\
\hline & Mild & $20.03 \pm 4.1$ & $10.7-27.8$ & 6.77 & $<0.0$ \\
\hline & moderate & $24.38 \pm 4.3$ & $18.1-30.3$ & & 1 \\
\hline \multirow{4}{*}{ Interface hepatitis } & Negative & $12.84 \pm 5.2$ & $10.2-27.4$ & & \\
\hline & $1 \backslash 4$ & $17.80 \pm 5$ & $11.2-18.4$ & 5.63 & $<0.0$ \\
\hline & $2 \backslash 4$ & $27.89 \pm 4.3$ & $18.1-28.3$ & & 1 \\
\hline & Plasma cells & $17.7200 \pm 6.02$ & $11.5-24.6$ & & \\
\hline \multirow[t]{4}{*}{ Type of cells } & Esinophils & $18.8200 \pm 5.36$ & $12.20-25.1$ & 2.21 & $>0.0$ \\
\hline & Mononuclear & $16.6769 \pm 5.37$ & $10.2-26.3$ & & 5 \\
\hline & Giant cells & $19.3000 \pm 11.45$ & $11.2-27.4$ & & \\
\hline & Lymphocytes & $21.7680 \pm 4.68$ & $10.7-28.3$ & & \\
\hline
\end{tabular}

Table (6) Correlation between serum autotoxin and some laboratory parameters

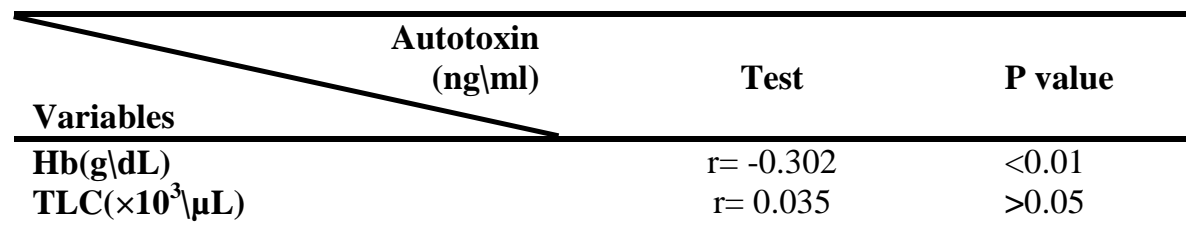




\begin{tabular}{|c|c|c|}
\hline platelet $\left(\times 10^{3} \backslash \mu \mathrm{L}\right)$ & $\mathrm{r}=-0.319$ & $<0.01$ \\
\hline total protein(g\dL) & $r=-0.307$ & $<0.01$ \\
\hline Albumin(gldL) & $\mathrm{r}=-0.025$ & $>0.05$ \\
\hline PT (Second) & $\mathrm{r}=0.329$ & $<0.001$ \\
\hline PTT(Second) & $\mathrm{r}=0.241$ & $<0.05$ \\
\hline INR & $\mathrm{r}=0.408$ & $<0.001$ \\
\hline AST(IUUL) & rho $=0.650$ & $<0.001$ \\
\hline $\operatorname{AIT}(I U \backslash L)$ & $\mathrm{rho}=0.388$ & $<0.001$ \\
\hline GGT(IUUL) & $\mathrm{rho}=0.453$ & $<0.001$ \\
\hline ALP(IULL) & rho $=0.652$ & $<0.001$ \\
\hline Total Bil.(mgldL) & rho $=0.582$ & $<0.001$ \\
\hline Direct Bil.(mg\dL) & $\mathrm{rho}=0.351$ & $<0.01$ \\
\hline
\end{tabular}

Table (7) Correlation between serum autotoxin and liver scoring systems, APRI, FIB4, liver span and spleen size

\begin{tabular}{|c|c|c|}
\hline Variables & Test & $P$ value \\
\hline Liver span & $r=0.520$ & $<0.001$ \\
\hline Spleen size & $\mathrm{r}=0.518$ & $<0.001$ \\
\hline MELD score & $\mathrm{r}=0.429$ & $>0.05$ \\
\hline PELD score & rho $=-0.026$ & $>0.05$ \\
\hline APRI & $\mathrm{r}=0.261$ & $<0.05$ \\
\hline FIB4 & $\mathrm{r}=0.286$ & $<0.05$ \\
\hline
\end{tabular}

Table (8) Performance of serum autotaxin in assessment of fibrosis

\begin{tabular}{cllllll}
\hline $\begin{array}{l}\text { Fibrosis } \\
\text { Stage }\end{array}$ & Cut off & AUC & Sensitivity\% & $\begin{array}{l}\text { Specificity } \\
\%\end{array}$ & PPV\% & NPV\% \\
\hline F 1 16 & $10.45 \mathrm{ng} / \mathrm{ml}$ & 0.961 & $97.6 \%$ & $93.8 \%$ & 81.6 & 96.8 \\
F 3\6 & $18.15 \mathrm{ng} / \mathrm{ml}$ & 0.984 & $85 \%$ & $93.8 \%$ & 75 & 96.8 \\
\hline
\end{tabular}

\section{Discssion}

In the current study, there was statistical significant difference between chronic hepatitis patients and control group regarding weight, weight/ centile, height, height/ centile, body mass index and body mass index/ centile as it was lower in chronic hepatitis group. This data run in accordance with Nunes et al., 2017(8) who studied 131 chronic liver disease patients and found that all anthropometric measurements that include weight, height, body mass index, mid upper arm circumference and triceps skinfold were significantly lower among cases than controls due to poor food intake, disturbances in absorption and digestion of nutritional substances in the gastrointestinal tract and impaired hepatic synthesis of energy substrates and these abnormalities gradually affect their anthropometric parameters. AlsoYounossi et al., 2018(9) who assessed weight, height and body mass index in adolescents infected with HCV before and after treatment with ledipasvir/ sofosbuvir and found that the patients had poor weight, height and body mass index before treatment and there is improvement after treatment. Also Murray, 2017(10) who studied 12 child infected with HCV and found that the children infected with $\mathrm{HCV}$ has low weight, height and body mass index due to malnutrition and growth retardation.
In the current study, there was statistical significant difference between chronic hepatitis patients and control group regarding $\mathrm{HB}$, platelet, total protein as they were lower in chronic hepatitis group than control group, while PT, INR, AST, ALT, GGT, ALP and bilirubin (total\& direct) were higher in chronic hepatitis group than control group. However, there was no statistical significant difference among chronic hepatitis group and control group regarding TLC, albumin and PTT. These results were in agreement with Abu-Taleb et al., 2019(11) who found that there was elevation in AST, ALT, GGT and bilirubin but HB was low. Also Ahmed et al., 2018 (12) who studied 771 patient with chronic liver disease for evaluating the stage of fibrosis and found that there was elevation in AST, ALT, INR and ALP but platelets and albumin were decreased with increasing fibrosis stage. Also Tsai et al., 2015 (13) who studied 144 positive anti-HCV child and 168 anti-HCVnegative child and found that platelets were lower in positive anti-HCV children than anti-HCV negative children but there was elevation in AST, ALT and bilirubin in positive anti-HCV children.

ALT and AST levels increase with the progression of liver disease as ongoing liver injury increases their 
release from mitochondria and fibrosis decreases this clearance. (14)

In the current study, there was statistical significant difference between chronic hepatitis patients and control group regarding serum autotaxin as it was higher in chronic hepatitis group (mean \pm SD was $19.65 \pm 5.56$ ) These results were in agreement with Yamazaki et al., 2017 (15) who studied serum autotaxin level on 593 chronic hepatitis $\mathrm{C}$ patients and found that serum autotaxin levels were significantly higher in patients than in healthy controls. They explained that autotaxin was rapidly taken up by liver sinusoidal endothelial cells, reduced clearance of autotaxin by the damaged or fibrotic liver may explain the elevated serum autotaxin levels found in patients with liver fibrosis. AlsoKremer et al., 2016 (16) who studied serum autotaxin level on 124 child with cholestatic disease and found that serum autotaxin activity was markedly elevated and correlated with itch intensity in children with cholestatic disease. AlsoFaujimori et al., 2018 (17) who studied 186 patients with non-alcoholic fatty liver disease (NAFLD) and 160 healthy, non-obese individuals were used as controls and found that serum autotaxin levels were significantly higher in patients than in healthy controls. Also She et al., 2018 (18) who studied 20 patient with chronic viral hepatitis B, 20 patient with hepatocellular carcinoma and another 20 healthy controls and found that serum autotaxinlevels were significantly higher in patients than in healthy controls and not only chronic viral hepatitis B but also in patients with hepatocellular carcinoma. Also with Pleli et al., 2014(19) who studied 220 patients with liver cirrhosis and 85 healthy controls and found that that serum autotaxin levels were significantly higher in patients than in healthy controls.

In the current study, there was statistical significant difference between serum autotaxin and sex as it was elevated in female patients. These results were in accordance with Yamazaki et al., 2017(15) who found that serum autotaxin levels were significantly higher in female patients than male patients as it was related to sex chromosomes. AlsoFaujimori et al.,2018 (17) who found that that serum autotaxin levels were significantly higher in female patients than male patients in nonalcoholic fatty liver disease (NAFLD). Also with Pleli et al., 2014 (19) found that that serum autotaxin levels were significantly higher in female patients than male patients with liver cirrhosis ،

In the present study, there were statistical significant differences between serum level of autotaxin and fibrosis index, hepatitis activity index and interface hepatitis as it increases with increase fibrosis index, hepatitis activity index and interface hepatitis. These findings were in agreement withYamazaki et al., 2017 (15) who found that there was positive relationship between serum autotaxin levels and fibrosis stages in chronic hepatitis $\mathrm{C}$ patients as it was increase with fibrosis severity. Also Wunsch et al., 2016 (20) who found that there was increasing in serum autotaxin levels with severity of liver fibrosis in children with cholestatic liver disease. Also Ando et al., 2018 (21) who found that there was increasing in serum autotaxin levels with severity of liver fibrosis and liver stiffness in chronic hepatitis $\mathrm{C}$ patients.

In the current study, there was positive correlation between serum autotoxin and liver enzymes (PT, PTT, INR, AST, ALT, GGT, ALP and bilirubin (total\& direct)), liver span, spleen size, APRI and FIB4 while there was negative correlation between serum autotaxin and hemoglobin, platelet and total protein. But there was no statistical significant correlation between serum autotoxin and total leucocytic count and albumin. These results were in agreement with Faujimori et al., 2018 (17) who found that serum autotaxin was significantly and positively correlated to the factors of age, weight, AST, APRI, FIB4, ballooning grade, fibrosis stage and duration of the disease in patients with non-alcoholic liver disease. Also Wunsch et al., 2016(20) who found that serum autotaxin was significantly and positively correlated to age, duration of the disease, ALP and AST concentrations as well as with INR values, platelet counts, hemoglobin levels, APRI and FIB4 in children with cholestatic liver disease. AlsoYamazaki et al., 2017 (15) who found that autotaxin was significantly positively correlated to AST, ALT, GGT, AFP, APRI and FIB4 while significantly negatively correlated to albumin and platelet count in chronic hepatitis C patients.

Autotaxin was metabolized by liver sinusoidal endothelial cells so in liver fibrosis, there was retarded degradation of circulating ATX due to liver sinusoidal endothelial cell dysfunction from liver fibrosis was considered a main mechanism. (22)

In the current study, the best cut off value of serum autotaxin was $10.45 \mathrm{ng} / \mathrm{ml}$ for detection of early fibrosis stage with sensitivity $97.6 \%$, specificity $93.8 \%$ and area under the curve (AUC) is 0.961 while the best cut off value of serum autotaxin for detection of moderate fibrosis was $18.15 \mathrm{ng} / \mathrm{ml}$ with sensitivity $85 \%$, specificity $93.8 \%$ and AUC is 0.984 . These results were in agreement with Yamazaki et al., 2017 (15) who found that there was elevation in serum autotaxin level with increasing fibrosis stage in chronic hepatitis $\mathrm{C}$ patients with the best cut off value of serum autotaxin was $0.9 \mathrm{mg} / \mathrm{l}$ for detection of early fibrosis stage and the best cut off value of serum autotaxin for detection of moderate fibrosis was $1.5 \mathrm{mg} / \mathrm{dl}$. Also withFaujimori et al., 2018 (17) who found that there was elevation in serum autotaxin level with increasing fibrosis stage in patients with NAFLD with the best cut off value of serum autotaxin was $0.73 \mathrm{mg} / \mathrm{l}$ for detection of early fibrosis stage and the best cut off value of serum autotaxin for detection of significant fibrosis was 1.19 $\mathrm{mg} / \mathrm{l}$.

\section{Conclusion}

Serum autotaxin may be a good non-invasive biomarker for liver fibrosis in Egyptian children with chronic hepatitis.

\section{References}


[1] A.Widodo, E.Soelaeman, A.Dwinanda and P.Narendraswaro. Chronic liver disease is a risk factor for malnutrition and growth retardation in children. Asia Pac. J.Clin. Nutr, Vol 26(1), pp5760, 2107.

[2] Pinto, A,C.R.Schneider and T.R. Themis Da Silveira . Cirrhosis in children and adolescents: An overview. World J Hepatol., Vol 7(3), pp 392-405, 2015.

[3] A.Boyd, O.Cain, A.Chauhan and GJWebb. Medical liver biopsy: background, indications, procedure and histopathology. Frontline gastro., Vol 2018, pp101139-101149, 2019.

[4] H.Ikeda and Y.Yatomi. Autotaxin in liver fibrosis. Clin Chim Acta., Vol 413(23-24). pp 1817-1821, 2012

[5] K.Ishak, A.Baptista, L.Bianchi, F.Callea, J.De Groote, F.Gudat et al. Histological grading and staging of chronic hepatitis. J Hepatol., Vol 22, pp 696-699, 1995.

[6] R.B.Freeman, R.H.Wiesner, J.P.Roberts, S. M.C.Diarmid, D.M.Dykstra and R.M.Merion. Improving liver allocation: MELD and PELD. Am J Transplant., Vol 4(9), pp114-31, 2004.

[7] T.I.Huo, H.C.Lin, J.C.Wu, F.Y.Lee, M.C.Hou, P.C.Lee et al. Proposal of a modified ChildTurcotte-Pugh scoring system and comparison with the model for end-stage liver disease for outcome prediction in patients with cirrhosis. Liver Transpl., Vol 12, pp 65-71, 2006.

[8] G.Nunes, C.A.Santos, R.Barosa, C.Fonseca, A.T.Barata and J.Fonseca. outcome and nutritional assessment of chronic liver disease patients using anthropometry and subjective global assessments. Arq Gastro-enterol., Vol 54(3), pp 225-231, 2017.

[9] Z.M.Younossi, M.Stepanova,W.Balistreri, K.Schwarz, K.F.Murray, P.Rosenthal et al. Healthrelated quality of life in adolescent patients with hepatitis $C$ genotype 1 treated with Sofosbuvir and Ledipasvir. J Pediatr Gastroenterol Nutr, Vol 66, pp 112-116, 2018.

[10] K.F.Murray. Hepatitis C virus infection in children. Gastroenterol Hepatol (N Y)., Vol 13(3), pp 184 187, 2017.

[11] A.Abou-Taleb, R.H.Ahmed and A.Elhennawy. Pediatric chronic liver diseases: A clinicopathological study from a Tertiary Care Center. Int J pediatr., Vol 7(4), pp 9305-9315, 2019.

[12] Z.Ahmed, U.Ahmed, S.Walayat, J.Ren, .K.Martin and H.Moole. Liver function tests in identifying patients with liver disease. Clin Exp Gastroenterol., Vol 11, pp 301-307, 2018.

[13] M.H.Tsai, K.H.Lin, K.T.Lin, C.M.Hung, H.S.Cheng, Y.C.Tyan et al. Predictors for early identification of hepatitis $\mathrm{C}$ virus Infection. Biomed Res Int. 2015; 2015:429290-429310.

[14] B.Nalpas, A.Vassault, A.LeGuillou, B.Lesgourgues, N.Ferry, B.Lacour et al. Serum activity of mitochondrial aspartate aminotransferase: A sensitive marker of alcoholism with or without alcoholic hepatitis. Hepatology., Vol 4, pp 893-986, 1984.

[15] T.Yamazaki, S.Joshita, T,Umemura, Y.Usami, A.Sugiura, N.Fujimori et al. Association of serum autotaxin levels with liver fibrosis in patients with chronic hepatitis C. Sci Rep., Vol 7, pp 46-65, 2017.

[16] A.E.Kremer, E.Gonzales, F.G.Schaap, R.P.Elferink, E.Jacquemin and Beuers. Serum autotaxin activity correlates with pruritus in pediatric cholestatic disorders. J. Pediatr. Gastroenterol. Nutr., Vol 62(4), pp 530-535, 2016.

[17] N.Fujimori, T.Umemura, T.Kimura, N.Tanaka, A.Sugiura, T.Yamazaki et al. Serum autotaxin levels are correlated with hepatic fibrosis and ballooning in patients with non-alcoholic fatty liver disease. World J Gastroenterol., Vol 24(11), pp 1239-1249, 2018.

[18] S.She, M.Yang, H.P.Hu, Y.Yang and H.Ren. Proteomics Based Identification of Autotaxin as an anti-Hepatitis B virus factor and a Promoter of hepatoma cell invasion and Migration. Cell PhysiolBiochem., Vol 45, pp 744-760, 2018.

[19] T.Pleli, D.Martin, B.Kronenberger, F.Brunner, V.Köberle, G.Grammatikos et al. Serum Autotaxin Is a parameter for the severity of liver cirrhosis and overall Survival in patients with liver Cirrhosis - A prospective cohort Study. PLoS One., Vol 9(7), pp 103532-103551, 2014.

[20] E,Wunsch, M.Krawczyk, M.Milkiewicz, J.Trottier, O.Barbier, M.Neurath et al. Serum autotaxin is a marker of the severity of liver Injury and overall survival in patients with cholestatic liver diseases. Journal of scientific reports., Vol 6, pp 30847-30871, 2016.

[21] W.Ando, H.Yokomori, F.Kaneko, M.Kaneko, K.Igarashi, and H.Suzuki. Serum Autotaxin concentrations reflect changes in liver Stiffness and Fibrosis after antiviral therapy in patients with chronic hepatitis C. HepatolCommun., Vol 2(9), pp 1111-1122, 2018.

[22] E.Kaffe, A.Katsifa, N.Xylourgidis, I.Ninou, M.Zannikou, V.Harokoposet al. Hepatocyte autotaxin expression promotes liver fibrosis and cancer. Hepatology., Vol 65(4), pp 1369-1383, 2017. 